\title{
Effect of soybean flour (Glycine max) and its inhibitors enzyme on endogenous protease activity in surimi-like gel elaborated with jumbo squid (Dosidicus gigas) during the storage at $4^{\circ} \mathrm{C}$ and $10^{\circ} \mathrm{C}$
}

Efecto de la harina de soya (Glycine max) y sus inhibidores enzimáticos sobre la actividad de proteasas endógenas en un gel tipo surimi elaborado de calamar gigante (Dosidicus gigas) durante el almacenamiento a $4^{\circ} \mathrm{C}$ y $10^{\circ} \mathrm{C}$

Efeito do farelo de soja (Glycine max) e inibidores de enzimas sobre a actividade de proteases endógenas em um surimi tipo gel feito de lula gigante (gigas Dosidicus) durante o armazenamento a $4{ }^{\circ} \mathrm{C}$ e $10^{\circ} \mathrm{C}$

DOI: http://dx.doi.org/10.23913/ciba.v6i11.62

Hugo Minor-Pérez

División de Ingeniería Química y Bioquímica, Tecnológico de Estudios Superiores de

Ecatepec, México

hminorperez@yahoo.com.mx

\section{Resumen}

El calamar gigante (Doisidicus gigas) es un producto marino abundante en las costas del pacífico de México. El calamar gigante tiene una alta actividad proteolítica endógena que puede afectar el proceso de gelificación e incrementar el deterioro del músculo de manto de calamar durante el almacenamiento o procesado. Los inhibidores de enzimas de soya pueden contribuir a la regulación biológica de la actividad proteolítica endógena de proteasas. Los cambios en la actividad proteolítica durante el almacenamiento a $4^{\circ} \mathrm{C}$ y $10^{\circ} \mathrm{C}$ fueron estudiados en un sistema modelo de extractos de enzimas alcalinas y extractos de inhibidores enzimáticos. Se elaboró un gel tipo surimi (GTS) con las proteínas miofibrilares del músculo de manto de calamar y harina de soya. Los resultados mostraron una reducción significativa $(\mathrm{p}<0.05)$ de la actividad proteolítica en el sistema modelo y en el GTS para ambas temperaturas. Durante el tiempo de almacenamiento los valores menores de actividad proteolítica específica fueron $14.3 \mathrm{UA} / \mathrm{mg}\left(4^{\circ} \mathrm{C}, 192 \mathrm{~h}\right)$ y 6.90 $\mathrm{UA} / \mathrm{mG}\left(10^{\circ} \mathrm{C}, 120 \mathrm{~h}\right)$ con los tratamientos de $30 \mathrm{mg} / \mathrm{mL}$ de extracto de inhibidores 
enzimáticos/70 mg/mL de extracto de enzimas. Además se obtuvo un valor de 77.80 $\mathrm{UA} / \mathrm{mg}\left(4^{\circ} \mathrm{C}, 144 \mathrm{~h}\right)$ y $80 \mathrm{UA} / \mathrm{mg}\left(10^{\circ} \mathrm{C}, 72 \mathrm{~h}\right)$ para el GTS elaborado con $50 \mathrm{~g}$ de harina de soya (base seca) y $50 \mathrm{~g}$ de proteína miofibrilar (base húmeda). Estos resultados sugieren que la harina de soya puede ser empleada como fuente de inhibidores de enzimas endógenas de calamar en geles tipo surimi de manto de calamar durante el almacenamiento a temperaturas de refrigeración y hasta valores de $10^{\circ} \mathrm{C}$.

Palabras clave: inhibidores enzimáticos, calamar gigante, actividad proteolítica, gel de surimi.

\section{Abstract}

Jumbo squid (Dosidicus gigas) is a marine product abundant in the Pacific shores of Mexico. It has high endogenous protease activity that affects gellation process and may to increase its deterioration during storage of muscle mantle fresh or processed. Enzyme inhibitors from soybean may to contribute to the biological regulation of this endogenous alkaline protease. Changes in proteolytic activity during the storage at $4^{\circ} \mathrm{C}$ and $10^{\circ} \mathrm{C}$ were studied in a model system of alkaline enzyme extracts of mantle muscle and enzyme inhibitors extracts. Surimi-like gel (SLG) elaborated with myofibrillar proteins from muscle mantle and soybean flour was also analyzed. Significant reduction $(\mathrm{P}<0.05)$ of proteolytic activity was observed in model system and SLG for both temperatures. During storage time lowest values were $14.3 \mathrm{AU} / \mathrm{mg}\left(4^{\circ} \mathrm{C}, 192 \mathrm{~h}\right)$ and $6.90 \mathrm{AU} / \mathrm{mg}\left(10^{\circ} \mathrm{C}, 120 \mathrm{~h}\right)$ with the treatments of $30 \mathrm{mg} / \mathrm{mL}$ protein of enzyme inhibitors extracts $/ 70 \mathrm{mg} / \mathrm{mL}$ protein of enzyme extracts and $77.80 \mathrm{AU} / \mathrm{mg}\left(4^{\circ} \mathrm{C}, 144 \mathrm{~h}\right)$ and $80 \mathrm{AU} / \mathrm{mg}\left(10^{\circ} \mathrm{C}, 72 \mathrm{~h}\right)$ for SLG elaborated using $50 \mathrm{~g}$ soybean flour (dry base) and $50 \mathrm{~g}$ myofibrillar protein (wet base). These results showed feasible to use soybean flour as a source of proteolytic inhibitors in surimi-like gels from jumbo squid during the storage at refrigeration conditions and temperature abuse conditions.

Key words: enzyme inhibitors, jumbo squid, proteolytic activity, surimi-like gel.

\section{Resumo}

A lula gigante (Doisidicus gigas) é um produto marinha abundante na costa do Pacífico do México. A lula gigante tem uma alta actividade proteolítica endógeno que podem afetar o processo de gelificação e aumentar a massa muscular deterioração manto da lula durante o armazenamento ou processamento. Inibidores da enzima de soja pode contribuir para a 
regulação biológica da actividade proteolítica endógena das proteases. Alterações na actividade proteolítica durante a armazenagem a $4{ }^{\circ} \mathrm{C}$ e $10^{\circ} \mathrm{C}$ foram estudados em um sistema modelo extrai alcalinas enzimas e inibidores de enzimas extractos. Tipo de gel de surimi (GTS), com proteínas musculares miofibrilares lula manto e farelo de soja foi preparado. Os resultados mostraram uma redução significativa $(\mathrm{p}<0,05)$ da actividade proteolítica no sistema de modelo e as GTS para ambas as temperaturas. Durante o tempo de armazenamento os valores mais baixos de actividade proteolítica específica foi de 14,3 $\mathrm{AU} / \mathrm{mg}\left(4^{\circ} \mathrm{C}, 192 \mathrm{~h}\right)$ e $6,90 \mathrm{AU} / \mathrm{mg}\left(10^{\circ} \mathrm{C}, 120 \mathrm{~h}\right)$ com os tratamentos de $30 \mathrm{mg} / \mathrm{mL}$ de inibidores de extrato enzima / $70 \mathrm{mg} / \mathrm{ml}$ de extracto de enzima. Também foi obtido um valor de 77,80 UA / $\mathrm{mg}\left(4^{\circ} \mathrm{C}, 144 \mathrm{~h}\right)$ e $80 \mathrm{AU} / \mathrm{mg}\left(10^{\circ} \mathrm{C}, 72 \mathrm{~h}\right)$ para o GTS feitas com $50 \mathrm{~g}$ de farinha de soja (base seca) e $50 \mathrm{~g}$ proteínas miofibrilares (base úmida). Estes resultados sugerem que a farinha de soja pode ser utilizada como uma fonte de enzimas inibidores endógenos do manto lulas de géis de surimi lula durante a armazenagem a temperaturas de refrigeração e para valores de $10^{\circ} \mathrm{C}$.

Palavras-chave: inibidores da enzima, lula gigante, a actividade proteolítica, gel de surimi.

Fecha Recepción: Junio 2016 Fecha Aceptación: Diciembre 2016

\section{Introduction}

Some proteins of marine origin are used for food production with high nutritional quality. Among others advantages some have low cost, availability and high essential amino-acids concentration (Hernández et. al., 1983). Jumbo squid (Dosidicus gigas) is a product abundant in shores of Mexico and its mantle muscle represents around half of edible portion (60-80\% product weight) (Slabyj et al., 1981). It has proteins with functional properties such as gel capacity formation (Gómez-Guillén et. al., 2003). In despite of these technological advantages, the mantle muscle commercialization is difficult due to its short shelf-life (Dublán et al., 2006; Ramírez-Suárez et al., 2008) which is attributed, among others causes, to the high endogenous proteolytic activity caused by releasing gastric and muscle enzymes during the post-capture (if there is not managed properly) (RamírezSuárez et al., 2008). 
Gómez-Guillén et al. (2003) and Dublán et al. (2006) mentioned that high endogenous proteolityc activity cause degradation of the heavy myosin molecule and therefore the gels have low ability to thermal gellation and low water holding capacity. Dublán et al. (2006) suggested that surimi gels also may lose mechanical optimal properties during the storage post-processing. Enzyme inhibitors from some legume seeds may to be alternative for its biological regulation (García-Carreño et al., 1996a; García-Carreño, 1996b; GarcíaCarreño and Hernández-Cortes, 2000; Ramírez et al., 2002; Ayensa et al., 2002, Shu-Guo and Guo-Jiang, 2005). García-Carreño and Hernández-Cortés (2000) define an enzyme inhibitor as any substance with capacity to reduce the measured rate of an enzymecatalyzed reaction. Enzyme inhibitors produce complexes protein-protein and there are reported at least 48 families with capacity to reduce the activity of serine, cysteine, metallo and aspartate protease (Otlewski et al., 2005). Soybean is an important legume for human diet. It has around of twenty enzyme inhibitors from the families I3, I12, I25, I29 (Rawlings et. al., 2004; Otlewski et al., 2005) and the majority are Kunitz and BowmanBirk type, specifics for trypsin and/or chymotrypsin.

Ramírez at al. (2002) reported that degradation of surimi gels is attributed mainly to cysteine proteases. However, there is little knowledge about the reduction of serine proteases activity, which are known may contribute considerably to the degradation of gels during the heat treatments at $50^{\circ} \mathrm{C}$ to $70^{\circ} \mathrm{C}$. The aim of this work was to study was evaluated the effect of enzyme inhibitors extracts from soybean fluor (Glycine max) on the proteolytic activity in a model system of endogenous alkaline enzyme and proteolytic activity reduction in a surimi-like gel (SLG) elaborated with myofibrillar proteins from mantle muscle and soybean flour was studied during the storage at $4^{\circ} \mathrm{C}$ and $10^{\circ} \mathrm{C}$.

\section{Materials and methods}

\subsection{Soybean}

\subsubsection{Physicochemical analysis}

Soybean (Gliycine max) seeds were obtained in Central Food Market "Central de Abastos de Ecatepec" in State of Mexico, Mexico. No harvest season and age were recorded. Soybean flour was prepared by milling the raw material and sieving a 40 " mesh until to get $0.42 \mathrm{~mm}$ final average particle size. The physicochemical analyses were: protein (A.O.A.C 42.014.), fat (A.O.A.C. 922.06.), humidity (A.O.A.C. 14.003.), ash (A.O.A.C. 14.006.) and total solids. 


\subsection{Jumbo squid mantle muscle}

\subsubsection{Raw material}

Jumbo squid (Dosidicus gigas) was caught at the Gulf of Mexico's coast and transported in ice to the Central Seafood Market "La Viga" in Mexico City within 12 h of capture. Mantle muscle samples were taken and immediately transported to our laboratory. In order to decrease surface microbial population the muscle was flamed with a torch; burt surface were cut with sterile knives. Muscle mantle was then sectioned into $50 \mathrm{~g}$ portions and packaged in polyethylene bags and stored at $-20^{\circ} \mathrm{C}$ until its analysis.

Ten grams of mantle muscle were packaged in sterile polyethylene bags sealed hermetically and stored at $4^{\circ} \mathrm{C}$ and $10^{\circ} \mathrm{C}$ during $240 \mathrm{~h}$ and $96 \mathrm{~h}$ respectively. Then were sampled every $24 \mathrm{~h}$ or $48 \mathrm{~h}$ for $\mathrm{pH}$ evaluation according to Dublán et al. (2006); $10 \mathrm{~g}$ was homogenized with $90 \mathrm{~mL}$ of water distilled in a conventional blender and connective tissue was removed. $\mathrm{pH}$ was determined in a digital $\mathrm{pH}$-meter Beckman (Q50, Beckman, Analytical Busines Unit, EUA).

\subsection{Enzyme extracts}

\subsubsection{Enzyme inhibitors extracts from soybean flour}

Enzyme inhibitors extracts were prepared dissolving $10 \mathrm{~g}$ of soybean flour in $30 \mathrm{~mL}$ of 50 $\mathrm{mM}$ phosphate buffer dissolution $(\mathrm{pH}$ 7). Samples then were agitated $2 \mathrm{~h}$ at ambient temperature and stored at $4^{\circ} \mathrm{C}$ during $24 \mathrm{~h}$ then they were centrifuged at $2000 \mathrm{~g}$ during 10 min in a Centrifuge Beckman model U94 8885, JA-14 rotor (Beckman, Palo Alto, CA.). Soluble protein concentration was determinate in the supernatant with enzyme inhibitors by biuret method (Gornall et al., 1949). One milliter of enzyme inhibitors extracts were stored in Eppendorf tubes at $-20^{\circ} \mathrm{C}$ until its analysis.

\subsubsection{Enzyme extracts from mantle muscle}

Endogenous enzyme extracts were obtained by homogenizing $50 \mathrm{~g}$ mantle muscle in 20 $\mathrm{mM}$ phosphate buffer $(\mathrm{pH} 7)$ at $4^{\circ} \mathrm{C}$ using a conventional blender. Then were centrifuged at $3000 \mathrm{~g}$ for $20 \mathrm{~min}$ (Dublán et al. 2006). Sediment was discarded and protein concentration was determinate in the supernatant by biuret method. Enzyme extracts were stored at $-20^{\circ} \mathrm{C}$. 


\subsection{Enzymatic analysis}

\subsubsection{Alkaline proteolytic activity}

Specific proteolytic activity (PA) was evaluated according Kunitz (1974) technique. Substrate was casein $(1 \%)$ dissolved in $20 \mathrm{mM}$ phosphate buffer $(\mathrm{pH} 7.0,0.9 \% \mathrm{NaCl})$ solution; $1 \mathrm{~mL}$ of buffer was added with $0.25 \mathrm{~mL}$ of enzyme extract. In order to promote the hydrolysis, samples were incubated at $30^{\circ} \mathrm{C}$ for $10 \mathrm{~min}$. This reaction was stopped with $0.75 \mathrm{~mL}$ trichloroacetic acid $(50 \%)$ and then was cooled to $4^{\circ} \mathrm{C}$ during $10 \mathrm{~min}$. Insoluble protein in acid was removed by centrifugation at $15000 \mathrm{~g}$ during $15 \mathrm{~min}$. Each treatment was analyzed by triplicate and the absorbance was read a wavelength of $280 \mathrm{~nm}$ in a Beckman Du Spectrophotometer model 650 (Fullerton, CA, USA). In accordance with the experimental conditions established by Yamaguchi et al. (1982), proteolytic activity was defined such as the amount of enzyme that produce a change of 0.001 in optical density, read a wavelength of $280 \mathrm{~nm}$ per minute. In this study control was enzyme extract no added with trichloroacetic acid. Proteolytic activity was calculated by the following equation:

$\mathrm{PA}=\left[\frac{(\text { abs } * \text { dilution })}{(0.001 * \text { time } * \mathrm{~mL} \text { enzyme extract })}\right]$

PA was determinate considering protein concentration in the enzyme extracts.

\subsubsection{Effect of enzyme inhibitors exracts on trypsin and enzyme extracts from mantle muscle}

To confirm the presence of enzyme inhibitors in the soybean flour studied, was evaluated proteolytic activity reduction using a enzyme control. Trypsin was prepared dissolving 0.1 $\mathrm{g}$ (Laboratories Difco, Detroit, USA) in $100 \mathrm{~mL}$ of $25 \mathrm{mM}$ phosphate buffer solution (pH 7.0). This stock sample was added with enzyme inhibitors extracts to obtain 0, 30, 40 and $50 \mathrm{mg} / \mathrm{mL}$ protein of trypsin/100, 70, 60 and $50 \mathrm{mg} / \mathrm{mL}$ protein of enzyme extract. PA in endogenous enzyme fraction was determinate for each treatment (2.4.1).

Enzyme extracts from squid mantle muscle (2.3.2) were also analyzed. The treatments were: $0,10,20$ and $30 \mathrm{mg} / \mathrm{mL}$ protein of enzyme inhibitor extracts/100, 90, 80 and 70 $\mathrm{mg} / \mathrm{mL}$ protein of enzyme extract. All samples were kept in tubes sterile and stored at $4^{\circ} \mathrm{C}$ and $10^{\circ} \mathrm{C}$ during $240 \mathrm{~h}$ or $96 \mathrm{~h}$ respectively. PA was evaluated for each temperature every $48 \mathrm{~h}$ or $24 \mathrm{~h}$ depending of storage conditions. 


\subsection{Surimi-like gel (SLG)}

\subsubsection{Myofibrillar proteins}

Myofibrillar proteins of jumbo squid mantle muscle were extracted according Ngapo et al. (1992) using saline solutions with low ionic force; $25 \mathrm{~g}$ of mantle muscle were homogenized in a conventional blender with ice and cold water in 1:2:1 w/w/v proportions. Mantle muscle solution was shaken at $4^{\circ} \mathrm{C}$ during $10 \mathrm{~min}$ and connective tissue was eliminated by filtration. Samples were centrifuged at $1500 \mathrm{~g}$ for $25 \mathrm{~min}\left(4^{\circ} \mathrm{C}\right)$ and the precipitated with myofibrillar proteins fraction were resuspended in $50 \mathrm{mM}$ phosphate buffer ( $\mathrm{pH} 7.0, \mathrm{NaCl} 0.6 \mathrm{M}$ ). To elaborate SLG, myofibrillar proteins (wet base) were added of soybean flour (dry base). The treatments were: (a) $50 \mathrm{~g}$ myofibrillar protein (wet base), (b) 50 g myofibrillar protein (wb) +25 g soybean flour (db) and (c) 50 myofibrillar protein $(w b)+50 \mathrm{~g}$ of soybean flour $(\mathrm{db})$. Gelification process was made with a heating from the ambient temperature to $70^{\circ} \mathrm{C}$, with a gradual increase of $1^{\circ} \mathrm{C} / \mathrm{min}$ (Dublán et al. 2006). The gel was cooled on ice during $30 \mathrm{~min}$. Fifty grams of SLG was packaged in sterile polyethylene bags sealed hermetically and stored at $4{ }^{\circ} \mathrm{C}$ and $10^{\circ} \mathrm{C}$ during $240 \mathrm{~h}$ and $96 \mathrm{~h}$. PA (2.4.1) was evaluated in the temperatures studied every $48 \mathrm{~h}$ or $24 \mathrm{~h}$.

\subsection{Specific proteolytic activity in SLG}

Endogenous proteolytic activity was determinate following the next procedure: were

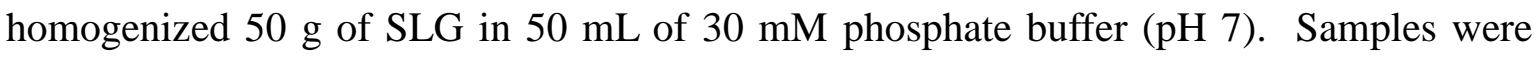
centrifuged at $3000 \mathrm{~g}$ for $20 \mathrm{~min}$. The sediment was discarded and protein was determined by biuret method in the supernatant. One milliliter were stored in tubes steriles at $-20^{\circ} \mathrm{C}$ until its enzymatic analysis.

Proteolytic activity (2.4.1) was evaluated in SLG using casein as substrate according Kunitz (1947). Analysis enzymatic were done every $48 \mathrm{~h}$ at $4{ }^{\circ} \mathrm{C}$ and $24 \mathrm{~h}$ at $10{ }^{\circ} \mathrm{C}$.

\subsubsection{Statistical analysis}

Samples were randomly allocated to complete factorial design to evaluate PA in enzyme extracts from mantle muscle and in SLG. The treatments studied in the model system were: $0,10,20$ and $30 \mathrm{mg} / \mathrm{mL}$ protein of enzyme inhibitors extracts/100, 90, 80 and 70 $\mathrm{mg} / \mathrm{mL}$ protein of enzyme extract from mantle muscle. In SLG were analyzed different soybean flour concentrations: 0,25 and $50 \mathrm{~g}(\mathrm{db})$ soybean flour/100, 75 and $50 \mathrm{~g}(\mathrm{wb})$ myofibrillar protein of mantle muscle. In both systems were evaluated temperature and 
time storage, $4^{\circ} \mathrm{C}$ and $10^{\circ} \mathrm{C}$ during $240 \mathrm{~h}$ and $96 \mathrm{~h}$. All treatments were subjected to an ANOVA and Bonferroni test using Statgraphics Plus 5.1 package (Statistical Graphics, USA). Significance levels were set at $\alpha=0.05$.

\section{Results and discussion}

3.1 Physicochemical analysis of soybean flour

Endogenous proteolytic activity from gastric or/and muscle enzyme is a phenomenon which quickly reduces the shelf-life of the majority of marine products. Some authors suggested (Otlewski et al., 2005; Rawlings et al., 2006; Ramírez et al., 2002) that protease inhibitors from soybean may to contribute in the reduction of enzyme activity in mantle muscle and products like surimi gels. Ensyme inhibitors mainly belong to Kunitz and Bowman-Birk families, specifics for trypsin and/or chymotrypsin and the greater are in cell wall and endosperm (Shu-Guo and Guo-Chiang, 2005). For this reason in this study was evaluated integral soybean flour. Its proximal analysis is shown in Table 1. From dried seeds was obtained $77.40 \%$ soybean flour with $23 \%$ of protein concentration.

\begin{tabular}{|c|c|c|c|c|c|}
\hline Sample & Protein & Fat & Ash & Humidity & Total solids \\
\hline Soybean flour & $23.01 \% \pm 1.0$ & $19.90 \% \pm 1,3$ & $14.01 \% \pm 0.75$ & $5.41 \% \pm 0.5$ & $44.58 \% \pm 5.0$ \\
\hline
\end{tabular}

\section{$3.2 \mathrm{pH}$ of mantle muscle during storage at $4^{\circ} \mathrm{C}$ and $10^{\circ} \mathrm{C}$}

$\mathrm{PH}$ is an important parameter that influence the shelf-life of mantle muscle during the storage (Ramírez-Suárez et al. 2008). pH increase promoted the endogenous proteolytic activity during the refrigeration and reduce muscle protein funtionality. At abuse storage temperature (e.g. $\left.10^{\circ} \mathrm{C}\right)$ this condition frequently is more accelerated. Dublán et al., (2006) suggested that endogenous proteolytic activity endogenous during storage at refrigeration or abuse temperatures is determined mainly by neutral and endogenous alkaline enzyme (pH 6.1-7.8). In this study, $\mathrm{pH}$ of mantle muscle during storage showed an increase from 6.2 to 6.5 at $4{ }^{\circ} \mathrm{C}$ and 7.2 at $10^{\circ} \mathrm{C}$ during $240 \mathrm{~h}$ (Figure 1). These results are agreement with the studies reported by Ramírez-Suárez et al., (2008) and Morán-Palacio, (2002) who mentioned a little $\mathrm{pH}$ increase during the time storage at low temperatures. 


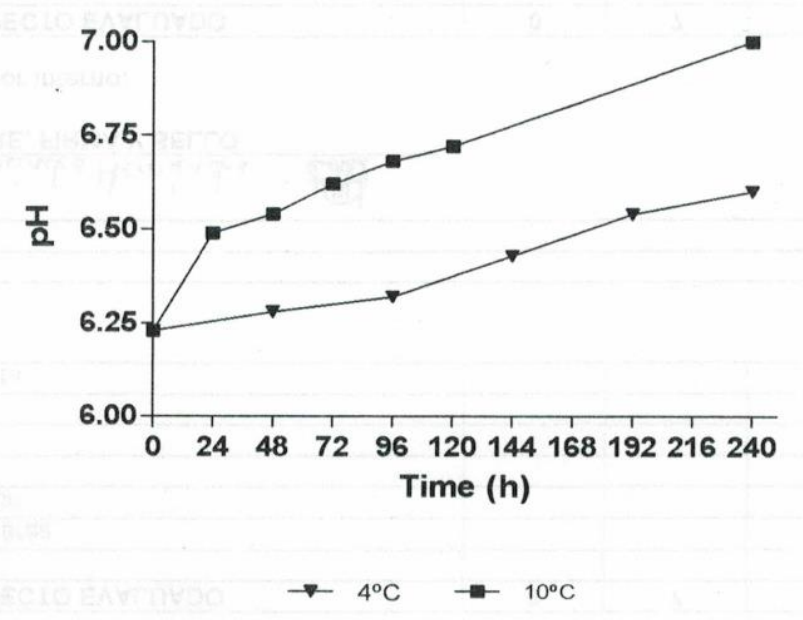

Figure 1. $\mathrm{pH}$ of mantle muscle at $4^{\circ} \mathrm{C}$ and $10^{\circ} \mathrm{C}$

\subsection{Enzymatic analysis}

3.3.1 Effect of enzyme inhibitors on trypsin and enzyme extracts of mantle muscle

Biological activity of enzyme inhibitors extracts was initially tested using a enzyme control. It was used trypsin reported as serin protease (Otlewski et al., 2005). The treatments are shown in Table 2. Enzymatic activity was reduced approximately $65 \%$ in treatments of $30 \mathrm{mg} / \mathrm{mL}$ protein of enzyme inhibitor $/ 70 \mathrm{mg} / \mathrm{mL}$ protein of trypsin. These results are similar to studies realized by others authors such as Ramirez et al., (2002) who observed a significant reduction in proteolytic activity when was evaluated by electrophoretic pattern the effect of enzyme inhibitors extracts from soybean. Sánchez et al., (1998) reported that raw protease inhibitors extracts obtained from bean, pea, chickpea and soybean reduced the enzymatic activity of trypsin (Trypsin Type III of beef, Sigma Chemical, Co. Pancreas) in 57-73\%. Sánchez et al. (1998) indicated in their study a reduction of $64.9 \%$ trypsin activity with soybean proteases inhibitors. In general the different results in these studies may to be attributed to different techniques used for inhibitors extraction and analysis. Also may affect different inhibitors concentrations in seeds due the variety and cultivation conditions of soybean (Shu-Guo and Guo-Huang, 2005).

Table 2. Proteolytic activity of trypsin treated with enzyme inhibitors extracts ${ }^{\mathrm{a}}$

\begin{tabular}{lr}
\hline Treatments & $\mathrm{PA}^{\mathrm{c}}$ \\
\hline $0^{\mathrm{b}}$ & $1,343.5 \pm 8.5^{\mathrm{a}}$ \\
30 & $435.0 \pm 15.0$ \\
40 & $850.5 \pm 20.0$ \\
50 & $964.3 \pm 15.0$ \\
\hline & \\
${ }^{\mathrm{a}} \mathrm{Mean}$ of three determinations & \\
${ }^{\mathrm{b}} \mathrm{mg} / \mathrm{mL}$ protein of trypsin/100, 70,60 o $50 \mathrm{mg} / \mathrm{mL}$ protein of enzyme extracts \\
${ }^{\mathrm{c}} \mathrm{PA}=$ specific proteolytic activity (AU/mg)
\end{tabular}


3.3.2 Effect of enzyme inhibitors extracts on endogenous enzyme of mantle muscle Some studies with low temperatures storage of squid mantle muscle reported that high endogenous proteolytic activity reduce its quality and functional characteristics (RamírezSuárez et. al., 2008. Dublán-García et. al., 2006). Mentioned changes in myofibrillar proteins that affect thermal gellation and also contribute to reduce the mechanical properties of surimi gels during the storage (Gómez-Guillén and Montero, 1997; GómezGuillén et. al., 1998). This effect is greater when the mantle muscle fresh or processed is exposed to temperatures above $4^{\circ} \mathrm{C}$ (refrigeration conditions).

Soybean inhibitors were analyzed in a model system. Enzyme inhibitors extracts and alkaline enzymes extracts were tested. Figure 2 shown the enzyme treatments studied throughout the time storage. At $4^{\circ} \mathrm{C}$ the lowest PA was observed until $192 \mathrm{~h}$. Conversely during the storage at $10^{\circ} \mathrm{C}$ the lowest PA was obtained at $120 \mathrm{~h}$. These enzyme activities were statistically differents in comparation with the control, when were evaluated enzyme inhibitors concentrations $(P<0.0001)$ and storage time $(P<0.001, P<0.0008)$ for both temperatures $4^{\circ} \mathrm{C}$ and $10^{\circ} \mathrm{C}$ respectively (Table 3 ). The lowest PA was obtained during the storage at $4^{\circ} \mathrm{C}$ in the treatments $20,30 \mathrm{mg} / \mathrm{mL}$ protein of enzyme inhibitors $/ 80,70 \mathrm{mg} / \mathrm{mL}$ protein of enzyme extractcs $(14.2 \mathrm{AU} / \mathrm{mg}$ and $14.3 \mathrm{UA} / \mathrm{mg})$. At $10^{\circ} \mathrm{C}$ also was observed the lowest PA in the same treatments, were obtained $18.2 \mathrm{AU} / \mathrm{mg}$ and $16.9 \mathrm{AU} / \mathrm{mg}$ respectively.

Statistical analysis (Table 3$)$ showed a significant differences $(P<0.0001)$ on proteolytic activity in all treatments added with enzyme inhibitors $(10,20$ and $30 \mathrm{mg} / \mathrm{mL}$ protein enzyme inhibitors/90, 80 and $70 \mathrm{mg} / \mathrm{mL}$ protein of enzyme extracts) compared with the sample control. Reduction of enzyme activity was significant from $48 \mathrm{~h}$ of storage at $4^{\circ} \mathrm{C}$ and $10^{\circ} \mathrm{C}$. There was no significant difference $(P>0.05)$ on endogenous proteolytic activity in both temperatures between the treatments of $10,20,30 \mathrm{mg} / \mathrm{mL}$ protein of enzyme inhibitors $/ 90,80$ or $70 \mathrm{mg} / \mathrm{mL}$ protein of enzyme extracts during the total time of study. 


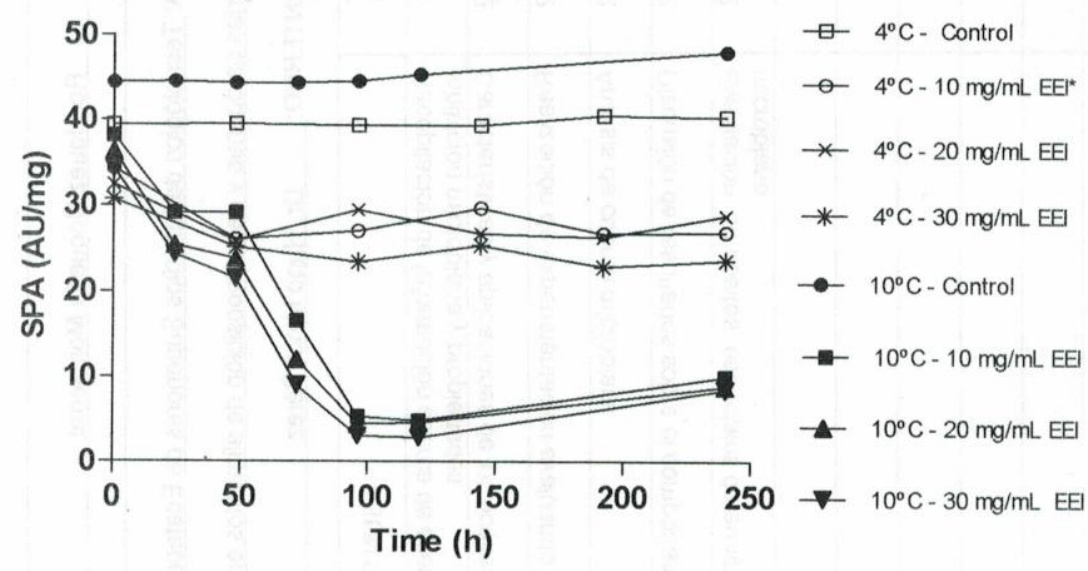

*Treatments: 0, 10, 20 or $30 \mathrm{mg} / \mathrm{mL}$ protein of enzyme inhibitors extracts $/ 100,90,80$ or $70 \mathrm{mg} / \mathrm{mL}$ protein of enzyme extracts. EIE: protein of enzyme inhibitors extracts

Figure 2. Proteolytic activity of enzyme extracts and enzyme inhibitors extracts during storage at $4^{\circ} \mathrm{C}$ and $10^{\circ} \mathrm{C}$.

Table 3. ANOVA for treatments of enzyme extracts and enzyme inhibitors extracts during the storage at $4^{\circ} \mathrm{C}$ y $10^{\circ} \mathrm{C}$

\begin{tabular}{lcccc}
\hline Response & $P>$ (model) & $\mathrm{R}^{2}$ & $P>$ & \\
\cline { 3 - 4 } & & & Enzyme inhibitor extracts & Time \\
\hline $\begin{array}{l}\text { Temperature: } 4^{\circ} \mathrm{C} \\
\text { PA (AU/mg) }\end{array}$ & 0.0001 & 0.9257 & 0.0001 & 0.001 \\
$\begin{array}{l}\text { Temperature: } 10^{\circ} \mathrm{C} \\
\text { PA (AU/mg) }\end{array}$ & & & & 0.0001 \\
\hline *PA: Specific proteolytic activity (AU/mg) & 0.0001 & 0.8868 & & 0.0008 \\
\hline
\end{tabular}


Table 4. Bonferroni test: treatments of enzyme extracts and enzyme inhibitors extracts during the storage at $4^{\circ} \mathrm{C}$ y $10^{\circ} \mathrm{C}$

\begin{tabular}{|c|c|c|c|c|c|c|c|c|c|}
\hline Time (h) & \multicolumn{9}{|c|}{ Enzyme inhibitors extracts $(\mathrm{mg} / \mathrm{mL}$ protein of enzyme inhibitors extracts / $100,90,80 \mathrm{o}$} \\
\hline \multicolumn{10}{|c|}{ Temperature: $4^{\circ} \mathrm{C}$} \\
\hline & Control & \multicolumn{2}{|c|}{$10 \mathrm{mg} / \mathrm{mL} \quad P>$} & Control & \multicolumn{2}{|c|}{$20 \mathrm{mg} / \mathrm{mL} \quad P>$} & \multicolumn{3}{|c|}{ Control $30 \mathrm{mg} / \mathrm{mL} \quad P>$} \\
\hline 0 & $39.40^{\mathrm{C}}$ & 29.47 & 0.05 & 39.4 & 28.71 & 0.05 & 39.40 & 26.77 & 0.05 \\
\hline 48 & 39.50 & 19.41 & 0.01 & 39.50 & 19.25 & 0.01 & 39.50 & 18.01 & 0.01 \\
\hline 96 & 39.30 & 18.14 & 0.01 & 39.30 & 16.00 & 0.01 & 39.30 & 15.11 & 0.01 \\
\hline 144 & 39.34 & 20.00 & 0.01 & 39.34 & 1424 & 0.01 & 39.34 & 16.79 & 0.01 \\
\hline 192 & 40.50 & 17.84 & 0.01 & 40.50 & 15.10 & 0.01 & 40.50 & 14.30 & 0.01 \\
\hline \multirow[t]{2}{*}{240} & 40.30 & 18.00 & 0.01 & 40.30 & 16.34 & 0.01 & 40.30 & 15.03 & 0.01 \\
\hline & \multicolumn{3}{|c|}{$10 \mathrm{mg} / \mathrm{mL} \quad 20 \mathrm{mg} / \mathrm{mL} \quad P>$} & \multicolumn{3}{|c|}{$10 \mathrm{mg} / \mathrm{mL} 30 \mathrm{mg} / \mathrm{mL} \quad P>$} & \multicolumn{3}{|c|}{$20 \mathrm{mg} / \mathrm{mL} 30 \mathrm{mg} / \mathrm{mL} P>$} \\
\hline 0 & 29.47 & 28.71 & 0.05 & 29.47 & 26.77 & 0.05 & 28.71 & 26.77 & 0.05 \\
\hline 48 & 19.41 & 19.25 & 0.05 & 19.41 & 18.01 & 0.05 & 19.25 & 18.01 & 0.05 \\
\hline 96 & 18.14 & 16.00 & 0.05 & 18.14 & 15.11 & 0.05 & 16.00 & 15.11 & 0.05 \\
\hline 144 & 20.00 & 14.24 & 0.05 & 20.00 & 16.79 & 0.05 & 14.24 & 16.79 & 0.05 \\
\hline 192 & 17.83 & 15.10 & 0.05 & 17.83 & 14.30 & 0.05 & 15.10 & 14.30 & 0.05 \\
\hline 240 & 18.00 & 16.34 & 0.05 & 18.00 & 15.03 & 0.05 & 16.34 & 15.03 & 0.05 \\
\hline
\end{tabular}

Temperature: $10^{\circ} \mathrm{C}$

\begin{tabular}{|c|c|c|c|c|c|c|c|c|c|}
\hline & Control & \multicolumn{2}{|c|}{$10 \mathrm{mg} / \mathrm{mL} P>$} & Control & $20 \mathrm{mg} / \mathrm{mI}$ & L $\quad P>$ & Control & \multicolumn{2}{|c|}{$30 \mathrm{mg} / \mathrm{mL} \quad P>$} \\
\hline 0 & $44.40^{\mathrm{C}}$ & 40.80 & 0.05 & 44.40 & 39.60 & 0.05 & 44.40 & 37.20 & 0.05 \\
\hline 24 & 44.50 & 27.40 & 0.01 & 44.50 & 23.50 & 0.01 & 44.50 & 18.30 & 0.01 \\
\hline 48 & 44.30 & 25.70 & 0.01 & 44.30 & 21.30 & 0.01 & 44.30 & 18.80 & 0.01 \\
\hline 72 & 44.34 & 21.60 & 0.01 & 44.34 & 18.80 & 0.01 & 44.34 & 17.30 & 0.01 \\
\hline 96 & 45.50 & 19.700 & 0.01 & 45.50 & 18.40 & 0.01 & 45.50 & 17.20 & 0.01 \\
\hline 120 & 45.30 & 20.00 & 0.01 & 45.30 & 18.20 & 0.01 & 45.30 & 16.90 & 0.01 \\
\hline & \multicolumn{3}{|c|}{$10 \mathrm{mg} / \mathrm{mL} \quad 20 \mathrm{mg} / \mathrm{mL} \quad P>$} & \multicolumn{3}{|c|}{$10 \mathrm{mg} / \mathrm{mL} 30 \mathrm{mg} / \mathrm{mL} P>$} & \multicolumn{3}{|c|}{$20 \mathrm{mg} 7 \mathrm{~mL} \quad 30 \mathrm{mg} / \mathrm{mL} P>$} \\
\hline 0 & 40.80 & 39.60 & 0.05 & 40.80 & 37.20 & 0.05 & 39.60 & 37.20 & 0.05 \\
\hline 24 & 27.40 & 23.50 & 0.05 & 27.40 & 18.30 & 0.05 & 23.50 & 18.30 & 0.05 \\
\hline 48 & 25.70 & 21.30 & 0.05 & 25.70 & 18.80 & 0.05 & 21.30 & 18.80 & 0.05 \\
\hline 72 & 21.60 & 18.80 & 0.05 & 21.60 & 17.30 & 0.05 & 18.80 & 17.30 & 0.05 \\
\hline 96 & 9.70 & 18.40 & 0.05 & 19.70 & 17.20 & 0.05 & 18.40 & 17.20 & 0.05 \\
\hline 120 & 10.0 & 18.20 & 0.05 & 20.0 & 16.90 & 0.05 & 18.20 & 16.90 & 0.05 \\
\hline
\end{tabular}

Mean of two determinations

${ }^{\mathrm{b}} \mathrm{mg} / \mathrm{mL}$ protein of enzyme inhibitors extracts $/ 90,80$ y $70 \mathrm{mg} / \mathrm{mL}$ protein of enzyme extracts

${ }^{\mathrm{c}} \mathrm{PA}=$ specific proteolytic acvitity $(\mathrm{AU} / \mathrm{mg})^{\mathrm{a}}$

${ }^{\mathrm{d} V}$ Values less 0.05 showed significant differences between treatments. Bonferroni test.

\subsubsection{Proteolytic activity in surimi-like gel}

Mantle muscle of jumbo squid has myofibrillar proteins with functional properties such as the gellification capacity (Gómez-Guillén et al., 2003). These characteristics represented an technological advantage that are used to develop foods like surimi gels or similar products. However, the gel quality frequently is affected by enzyme activity (Ramirez et al., 2002). Ramírez et al. (2002) mentioned when studied different species of fish, that surimi gels degradation is mainly attributed to the cistein protease. Others authors reported that serin protease affected significantly to gel degradation during heat treatments of $50^{\circ} \mathrm{C}$ - 
$70^{\circ} \mathrm{C}$. Ebina et al. (1995) and Gómez-Guillén et al. (2002) observed that decrease of rheological properties in muscle cephalopods such as squid is also related to serin protease activity at $40^{\circ} \mathrm{C}$. Changes in alkaline proteolytic activity in surimi-like gel (SLG) during the storage at $4^{\circ} \mathrm{C}$ and $10^{\circ} \mathrm{C}$ is shown in Figure 3.

During the storage at $4^{\circ} \mathrm{C}$ the lowest PA was observed at $48 \mathrm{~h}(20 \mathrm{AU} / \mathrm{mg})$. Conversely during the storage at $10^{\circ} \mathrm{C}$ the lowest PA was observed at $48 \mathrm{~h}(30 \mathrm{AU} / \mathrm{mg})$. This significant enzyme activity reduction was obtained when where analyzed SLG elaborated with $50 \mathrm{~g}$ of soybean flour (bs) and $50 \mathrm{~g}$ of protein myofibrillar (wb). Enzyme activities were statistically differents in comparation with treatment control, when were analyzed soybean flour concentration $(P<0.0005, P<0.0001)$ and storage time $(P<0.0048, P<0.0030)$ for both temperatures $4^{\circ} \mathrm{C}$ and $10^{\circ} \mathrm{C}$ respectively (Table 5).

Statistical analysis showed that there was not a significant difference $(P>0.05)$ between treatments control and $30 \%$ of soybean flour in both temperatures. There was a significant difference $(P<0.05)$ between control and treatments of $50 \%$ soybean flour during storage time from $144 \mathrm{~h}$ at $4^{\circ} \mathrm{C}$. For the treatments during the storage this differences were observed at $10^{\circ} \mathrm{C}$ from $72 \mathrm{~h}$. In the comparation of SLG prepared with $30 \%$ and $50 \%$ soybean flour only was observed significant differences between $144 \mathrm{~h}$ and $192 \mathrm{~h}$ time storage at $4^{\circ} \mathrm{C}$. This behavior was obtained at $72 \mathrm{~h}$ storage time at $10^{\circ} \mathrm{C}$. In general as was mentioned previously the lowest specific proteolytic activity was observed in all the treatments of $50 \%$ soybean flour.

The increase in PA during storage time, possibly is due to effect of high $\mathrm{pH}$ that promoted major endogenous enzyme activity (Dublán et. al. 2006). Even when in literature there is not definitive explanation of this behavior, Rawlings et al., (2004) suggested that due to the inhibitors belong to Kunitz and Bowman-Birk families, have a Laskoswki mechanism action. They have a reactive site that interacts with active enzyme site until to get a balance between the complex enzyme-inhibitor and inhibitor with a equilibrium constant of 1 . Therefore, enzyme inhibitors interact with enzymes to obtain the greatest reduction of endogenous enzymatic activity. 


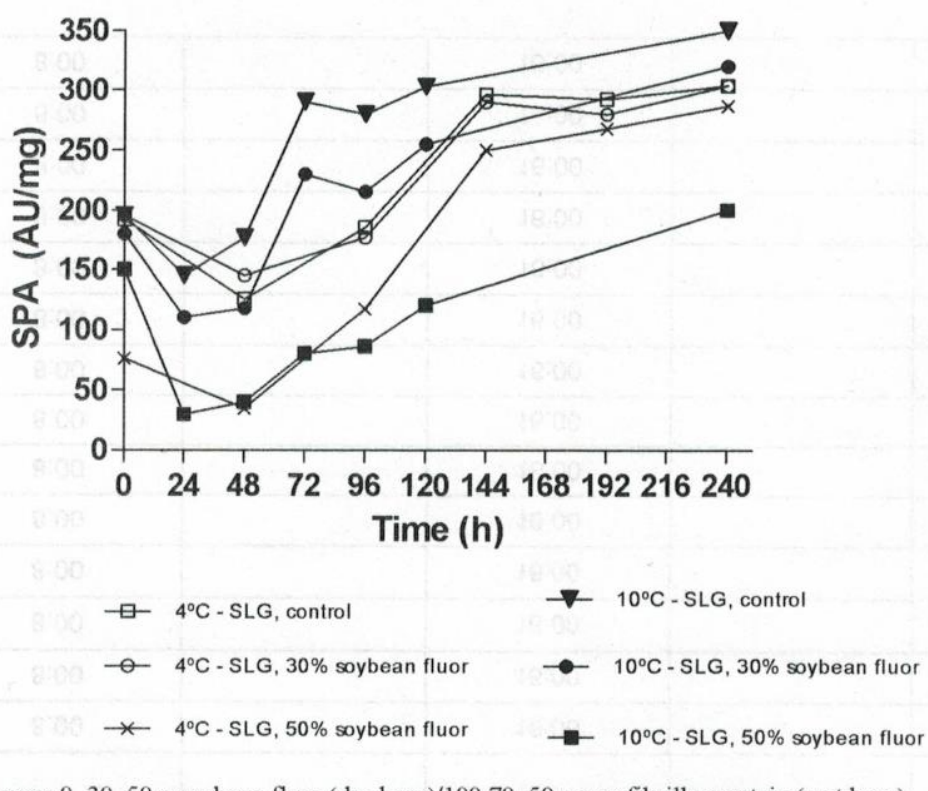

*The treatments were: $0,30,50 \mathrm{~g}$ soybean flour (dry base)/100,70, $50 \mathrm{~g}$ myofibrillar protein (wet base)

Figure 3. Proteolytic activity in surimi-like gel added to soybean flour during storage at $4^{\circ} \mathrm{C}$ and $10^{\circ} \mathrm{C}$.

Table 5. ANOVA for the treatments in surimi-like gel added with soybean flour during storage at $4^{\circ} \mathrm{C}$ and $10^{\circ} \mathrm{C}$.

\begin{tabular}{|c|c|c|c|c|}
\hline \multirow[t]{2}{*}{ Response } & \multirow[t]{2}{*}{$P>($ model $)$} & \multirow[t]{2}{*}{$\mathrm{R}^{2}$} & \multicolumn{2}{|c|}{$P>$} \\
\hline & & & Soybean flour & Time \\
\hline \multicolumn{5}{|l|}{ Temperature: $4^{\circ} \mathrm{C}$} \\
\hline PA (AU/mg) & 0.0001 & 0.8749 & 0.0005 & 0.0048 \\
\hline \multicolumn{5}{|l|}{ Temperature: $10^{\circ} \mathrm{C}$} \\
\hline PA (AU/mg) & 0.0001 & 0.913 & 0.0001 & 0.0030 \\
\hline
\end{tabular}




\section{Bibliography}

AOAC. 2000. Official Methods of Analysis. Association of Official Analytical Chemist. EUA. 17 Edition.

Ayensa, M.G., Montero, M.P., Borderías, A.J. y Hurtado, J. L. 2002. Influence of some protease inhibitors on gelation of squid mantle. Journal of Food Science. 67(5):1636-1641

Dublán, G. O., Cruz. C.R., Guerrero, L.I. y Ponce, A.E. 2006. Effect of refrigerated storage on proteolytic activity, physicochemical and microestructural properties of giant squid (Dosidicus gigas) mantle muscle. Journal of Muscle Foods 17:1-24

Dublán, G.O. 2006. Evaluación de los cambios estructurales y fisicoquímicos del manto de calamar gigante (Dosidicus gigas) durante el almacenamiento en refrigeración o congelación. Tesis de Doctorado en Biotecnología. UAM Iztapalapa

Ebina, H., Nagashima, Y., Ishizaki, S. Takeshi, T. 1995. Myosin heavy chain-degrading proteinase from spear squid muscle. Food Research International 28:31-García, C. F.L., Navarrete, A., Díaz, L. M., Hernández, C. M. P. y Ezquerra, J.M. 1996a. Proteinase inhibition of fish muscle enzymes using legume seed extracs. Journal of Food Protection. 59:312-318

García-Carreño y Hernández-Córtes, P. 2000. Use of protease inhibitors in seafood products. En: Seafood enzymes.Utilization and influence on postharvest seafood quality. Editores: Haard, N.F. y .Simpson, B.K. Editorial Haard \& Simpson.

García-Carreño, F. L. 1996b. Proteinase inhibitors. Trends in Food Science and Technology 7:197-203

Gómez.Guillén, M.C., Hurtado, J.L., Montero, P. 2002. Autolisys and protease inhibiton effects on dynamic viscoelastic propierties during thermal gelation os squid muscle. Journal of Food Science 67(7):2491-6.38 
Goméz-Guillén, M. C., \& Montero, P. (1997). Improving of giant squid (Dosidicus gigas) muscle gelation by using gelling ingredients. Z Lebensm Unters Forsch A, 204, $379-384$

Gómez-Guillén, M. C., Martinez-Alvarez, O., \& Montero, P. (2003). Functional and thermal gelation properties of squid mantle proteins affected by chilled and frozen storage. Journal of Food Science, 68(6), 1962-1967.

Gómez-Guillén, M. C., Montero, P., Solas, M. T., \& Borderías, A. J. (1998). Thermally induced aggregation of giant squid (Dosidicus gigas) mantle proteins: Physicochemical contribution of added ingredients. Journal of Agricultural and Food Chemistry. 46(9), 3440-3446.

Gornall, A. G., Bardawill, C. J. and David, M. M. (1949). Determination of serum proteins by means of the biuret reaction. Journal of Biological Chemistry. 177,751-766.

Hernández, M., Chávez, A. and Burges, H. 1983. Valor nutritivo de los alimentos mexicanos. Tablas de uso práctico. Instituto Nacional de la Nutrición Salvador Zubirán, México.

Kunitz., M., 1947. Cristaline soybean trypsin inhibitor. II General properties. Journal of General Physiology. 30:291-310

Moran-Palacio, E. F. (2002). Comportamiento bioquímico postmortem del calamar gigante (Dosidicus gigas) almacenado en hielo y su relación con parámetros de calidad. Master thesis. A.C. Hermosillo, Sonora, Mexico: Centro de Investigación en Alimentación y Desarrollo.

Ngapo, T., Wilkinson, B., Chong, R. y Haisman, D. 1992. Gelation of bovine myofibrillar protein induced by 1,5 -Gluconate. $38^{\text {th }}$ International Congress of Meat Science and Technology. Clemort Ferrand, France, pp 1095-1098 
Otlewski, J., Jelen, F., Zakrzwska and Oleksy, A. 2005. The many faces of proteaseprotein inhibitior interaction. European Molecular Biology Organization. 24 (7): $1303-1310$

Ramírez, J.A., García-Carreño, E.L., Morales, O.G. and Sánchez, A. 2002. Inhibition of Modori-Associated Proteinase by legume seed extracts in Surimi production. Journal of Food Science. 67: 578-581

Ramírez-Suárez, J., Ibarra-León, L.R., Pacheco-Aguilar, R., Lugo-Sánchez, M.E., García Sánchez, G. y Carvallo-Ruiz, G. 2008. Physicochemical and funtional changues in jumbo squid (Dosidicus gigas) mantle muscle during ice storage. Food Chemistry. 111:586-591

Rawlings, N., Tolle, D. P. and Barret, J. A. 2004. Evolutionary families of peptidase inhibitors. Biochemical Society. 378: 705-716

Sánchez, A., Ramírez, J. A., Morales, O.G y Montejano, J.G. 1998. Detección de inhibidores de proteasas en extractos de leguminosas y su efecto sobre proteasas endógenas del músculo de pescado. Ciencia y Tecnología de Alimentos. 2(1):12-19

Shu-Guo, F. and Guo-Jiang, W. 2005. Characteristics of plant proteinase inhibitors and their applications in combating phytophagous insects. Botanical Bulletin of Academia Sinica, 46:273-292

Slabyj, B. M., Ramsdell, G.E. and True, R.H. 1981. Quality fo squid, Illex illecebrosus mantles canned in oild. Marine Fisheries Review, 43: 15-21

Yamaguchi, T., Yashita, Y., Takeda, I. y Kiso, H. 1983. Enzymes in green asparagus kiwi fruit and muit: Ocurrence and partial characterization. Agriultural and Biological Chemistry 46(8): 1983-1986 